\title{
The Effect of Application Endophytic Fungus Trichoderma spp. and Fusarium spp. to Control Bacterial Wilt in Chilli Pepper
}

\author{
Ana Feronika Cindra IRAWATI ${ }^{1, *}$, Kikin Hamzah MUTAQIN ${ }^{2}$, \\ Maggy Tenawidjaja SUHARTONO ${ }^{3}$ and Widodo ${ }^{2}$ \\ ${ }^{I}$ Assessment Institute for Agricultural Technologi of Jakarta, Pasar Minggu, Jakarta Selatan, Indonesia \\ ${ }^{2}$ Departement of Plant Protection, Institut Pertanian Bogor (Bogor Agriculture University), Indonesia \\ ${ }^{3}$ Department of Food and Technology, Bogor Agriculture University, Indonesia
}

("Corresponding author’s e-mail: taniutun@gmail.com; ana.feronika@gmail.com)

Received: 10 January 2017, Revised: 17 September 2018, Accepted: 29 October 2018

\begin{abstract}
Endophytic fungi have the ability to produce secondary metabolites that promote plant growth and increase plant resistance to biotic and abiotic stresses. A plant disease is an important biotic stress that need to be controlled. However, the potential use of endophytic fungi to induce resistance against bacterial wilt disease in chilli pepper (Capsicum annuum L.) caused by Ralstonia solanacearum has not been widely reported. Thus, this research aimed to determine the potential of endophytic fungi in suppressing development of bacterial wilt disease in chili. The study was conducted using three endophytic fungi such as Fusarium solani f.sp. phaseoli isolates AC-2.13 and AC-3.18, and Trichoderma asperellum AC-4.4. The test used nine treatments, i.e. 3 single treatments, four combination treatments, streptomycin, and control. The results showed that application of endophytic fungi $F$. solani f.sp. phaseoli and T. asperellum either in single or combination treatments reduced development of bacterial wilt in chili with inhibition rate of 12.5 to $50 \%$. Applications of combined endophytic fungi were not always inhibiting development of bacterial wilt in chili. Furthermore, the ability to suppress disease development by endophytic fungi was not always followed by its ability to increase crop yield. $F$. solani f.sp. phaseoli isolate AC-44 have the highest potential of endophytic fungi in controlling $R$. solanacearum. In the biochemical evaluation, $F$. solani f.sp. phaseoli showed an increase of several compounds activity in chili such as total phenol, peroxidase (PO), polyphenol oxidase (PPO), $\beta$-glucanase, and phenylalanine aminaliase (PAL).
\end{abstract}

Keywords: Biocontroling, endophytic fungi of Fusarium solani f.sp. phaseoli, Trichoderma asperellum

\section{Introduction}

Bacterial wilt caused by Ralstonia solanacearum is one plant disease which impaired the production of chilli pepper. To control bacterial wilt disease on chilli, farmers are suggested to apply a comprehensive manner such as integrated disease management. One of the integrated controlling system principles is the biological control. Several studies about biological control of $R$. solanacearum in some Solanaceae crops have been reported. In fact, common studies in biocontrolling bacterial wilt disease reported some applications of antagonist rhizospheric microbes. These include fungi, bacteria, mycorrhiza, and endophytic microbes [1-5].

Endophytic microbe are microorganisms that live inside the plant tissues at a certain period. They form colonies and give no/a few negative effects to the host. Generally, the colonization of endophythic bacteria and the appearance of these disease symptoms may not necessarily be reflected in these plants [6]. This is because antagonistic microorganisms optimized the equilibrium between plant defense 
http://wjst.wu.ac.th

responses and virulence level of endophytes. Although the application of endophytic microbes in increasing plant resistance to several kinds of pathogen on chilli pepper has also been widely studied [710], the study on the application of endophytic fungi to control bacterial wilt disease on chilli pepper in field scale and mechanism of resistance induction have not been done. Thus, there is a need to figure out the effects of endophyte fungus (Fusarium spp. and Trichoderma spp.) application on the development of bacterial wilt disease on chilli pepper in the field.

\section{Materials and methods}

These experiments were conducted from April 2015 to April 2016 in Laboratory of Microbiology, Assessment Institute for Agricultural Technology of Jakarta (BPTP Jakarta), field trials in South Jakarta, and Laboratory of BIORIN PAU- Bogor Agricultural University (IPB), Indonesia. The cultivar of chilli used in this research was Tanjung-2 that has been known susceptible to $R$. solanacearum. The endophytic fungus used were Fusarium solani f.sp. phaseoli (isolates AC-2.13 and AC-4.4) and Trichoderma asperellum, (isolate AC-3.18) that were supplied from the collection of Laboratory of Mycology, Department of Plant Protection - IPB, and BPTP Jakarta.

\section{Experimental design}

Experimental design used in this research was Randomized Block Design (RBD) with 9 treatments and 3 replications. The treatments were: 1) F. solani f.sp. phaseoli isolate AC-2.13; 2) T. asperellum isolate AC-3.18; 3) F. solani f.sp. phaseoli isolate AC-4.4; 4) F. solani f.sp. phaseoli isolate AC-2.13+ Trichoderma sp. isolate AC-3.18; 5) F. solani f.sp. phaseoli isolate AC-2.13 and AC-4.4; 6) Trichoderma sp. isolate AC-3.18+ Fusarium sp. isolate AC-4.4; 7) F. solani f.sp. phaseoli isolate AC-2.13 and AC4.4+ Trichoderma sp. isolate AC-3.18; 8) streptomycin; and 9) control (without bacteriside or endophytic fungus);

Bactericide of streptomycin was applied 1 day after the application of pathogenic bacteria by recommended concentration and dose from the company. The aftershocks of applications were done once a week after the first application. Maintenance activities such as watering and fertilizing plants were applied according to the standard cultivation technique.

\section{Preparation and application of endophytic Fungus}

The endophytic fungi were inoculated on Potato Dextrose Agar (PDA) or Potato Dextrose Broth (PDB) for 5 - 7 days in the temperature of $27-30{ }^{\circ} \mathrm{C}$. Incubatred cultures were suspended in $100 \mathrm{ml}$ sterile aquades to obtain the approximate concentration of $10^{7} \mathrm{cfu} \mathrm{ml}^{-1}$. This was a modification metode from Ramdan et al. [9].

Firstly, chilli pepper seeds were surface-sterilized, then soaked for $12-24 \mathrm{~h}$ in suspension of endophytic fungi that were prepared before. The control treatment was conducted without inoculation of endophytic fungi. Subsequently, the seeds were planted using non-sterile growth medium (soil + manure + husk fuel $=1: 1: 1)$ in the nursery. The selection of seeds was done when the plants had already grown 3-4 leaves, which was about two weeks.

The second application was given at 28 days after the planting (dap) was done. The plants were watered as much as $10 \mathrm{~mL}$ suspension endophytic fungus, using the same propagules density with the first application. Fertilization using 1 g. $\mathrm{L}^{-1}$ standard fertilizer (Nitrogen, Phosphate, and Potassium/NPK) was done after the seed had already grown. Refertilization using NPK was done 10 days before transplanting, with similar doses with the early fertilization. After 5 weeks, the seedlings were transplanted into new media non steril (soil + manure + husk fuel $=2: 1: 1+10 \%$ Dolomit) in a polybag measuring $40 \times 40 \mathrm{~cm}^{2}$. 


\section{Preparation and application of pathogenic bacteria: Ralstonia solanacearum}

The suspension of bacteria used was obtained from bacterial ooze ( $R$. solanacearum) from chilli pepper plants with bacterial wilt symptom. Diseased roots were cleaned from soil and other particles, then rinsed with water, and disinfected using $70 \%$ alcohol. The cut tissues were placed in a sterile water to observe the bacterial ooze. Subsequently, the available bacterial ooze were suspended to obtain the approximate concentration of $10^{8} \mathrm{cfu} \mathrm{ml}^{-1}$. Each plant was applied with $250 \mathrm{ml}$ of bacterial inoculum. Incubation period was obtained by observing presence of wilting symptom in examined plants especially in control treatment. The result of inoculated plantes was observed $4-5$ weeks after transplanting as indicated by the symptoms in some parts of the plants such as wilt.

\section{Variabels of observation}

The observation was conducted once a week. Some of the variables of observations were (1) The intensity of the disease included disease incidence,disease severity, and area under the disease progress curve (AUDPC)), (2) Agronomical characteristics such as plant height, number of branch, stem diameter, width of the canopy, and the area under the growth progress curve (AUGPC)), (3) Plants yield (number of fruit and weight in the maturity level at least $70 \%$ ), and (4) Activity of biochemical compound associated with plant defense system against pathogen.

The observations of agronomical characteristics were done once a week since first day of planting and after transplanting. Meanwhile, the observation of plant yield was measured 5-7 days after harvesting. Observations of disease incidence (DI) and disease severity (DS) were performed on 0, 2, 4, and 6 weeks after pathogen inoculation. Disease incidence was measured by calculating number of infected plants compared to number of applied plants. Disease severity was measured by calculating the proportion of infected area as compared to all of the parts of the plant.

Disease severity measurement were referenced to wilt score levels reported by Arwiyanto et al. [2]:

$0=$ healthy plant $3=41-60 \%$ wilting leaves

$1=1-20 \%$ wilting leaves $4=61-80 \%$ wilting leaves

$2=21-40 \%$ wilting leaves $5=>80 \%$ wilting leaves until dead

Disease severity were calculated based on the following formula:

$\mathrm{DS}=\frac{\sum_{\mathrm{i}=0}^{\mathrm{n}} \mathrm{ni} \times \mathrm{vi}}{\mathrm{N} \times \mathrm{Z}} \times 100 \%$

where $D S$ is disease severity (\%), vi is score level refers to each plant, $n i$ is number of wilting plants with certain scoring-i value, $N$ is number of plants observed, and $Z$ is the highest score level (=5).

The AUDPC and AUGPC be calculated using the midpoint method Campbell and Madden (1990) cit. Reynolds and Neher, [11]:

$$
\mathrm{AUDPC}=\mathrm{AUGPC}=\sum_{i}^{n=1}\left[\frac{y_{i}+y_{i+1}}{2}\right]\left(\mathrm{t}_{\mathrm{i}+1}-\mathrm{t}_{\mathrm{i}}\right)
$$

where $n$ is number of disease assessments, $y$ is disease intensity, $t$ is time, $i$ and $i+1$ are representing observations from 1 to $n$.

The analysis of biochemical was the content of phenols total, protein total, peroxidase (PO), polyphenol oxidase (PPO), $\beta$-glucanase, and phenilalanin amine lyase (PAL). It was focused on plant vegetative phase, i.e. a week before and after inoculation of pathogenic bacteria. The analysis of these compounds was done according to the methods recommended by Murthy et al. [12]. 


\section{Data analysis}

Data analysis was carried out using SPSS 16.0 version and analyzed by analysis of variance (ANOVA), with post hoc analysis by Duncan Multiple Range Test (DMRT) $\alpha=0.05$.

\section{Results and discussion}

The effects of endophytic fungal to the growth of chilli seeds

Based on the observations, application of singly or in combination of endophyte fungi Fusarium solani f.sp. phaseoli (isolates AC-2.13 and AC-4.4) and Trichoderma asperellum (isolate AC-3:18) was not significantly improving the growth of chilli seedlings. However, in general, it was known that the treatment of applications fungus endophyte in combination tended to further improve the growth of seedlings from the use of a single, particularly on the use of combinations of isolates AC-3.8 and AC-4.4 (Figure 1). Furthermore, based on the preliminary tests, it was known that the three of endophytic fungi have the potential to suppress the development of bacterial wilt disease by $R$. solanacearum (Figure 2). The isolates were isolated from the healthy root tissue of chilli. Fungi obtained from the root tissue of chilli was dominated by potential pathogenic to pathogenic fungi (tends to be pathogenic) when tested in vitro. However, vivo can trigger seed growth. Similarly, the isolates were able to trigger the growth through in vitro testing, but this was not necessarily consistent to trigger growth of chilli in nursery. In addition, the isolates that were best at triggering plant growth were not necessarily good in response to various environmental stresses, especially abiotic stress by pathogens [13].

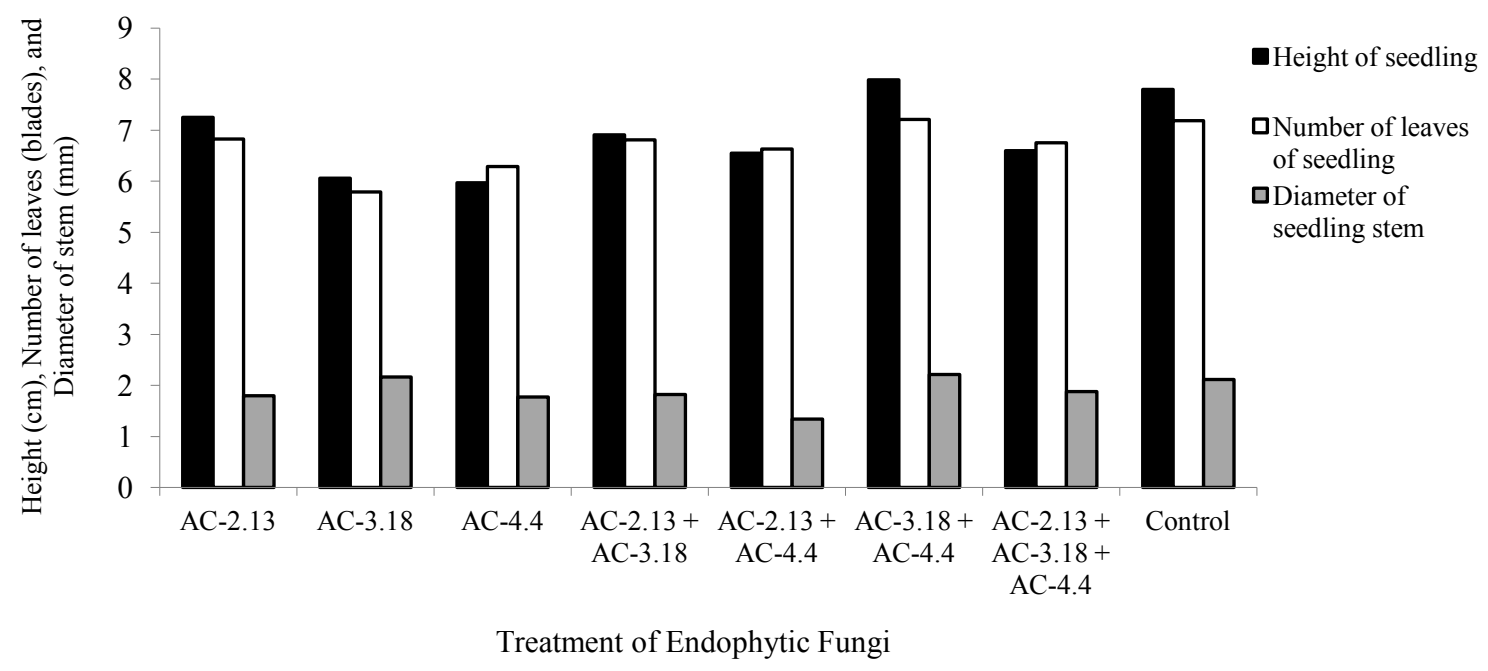

Figure 1 The effects of endophytic fungal isolates were applied singly or in combination to the growth rate of chilli pepper seeds, five weeks after seeding (isolates AC-2.13 and AC-4.4 are Fusarium solani f.sp. phaseoli; isolate AC-3.18 = Trichoderma asperellum).

The endophytic microbes were able to trigger the growth of the plants. According to Anand et al. [14], these capabilities can be performed by several direct and indirect mechanisms. The direct mechanism includes the productions of growth regulator compounds or the increase in the nutrient availability which can increase the growth of the plants (such as auxin, cytokinin, and nitrogen fixation). The indirect mechanism was done through the suppression of pathogen. The compounds are also known to be produced directly by the endophytic fungus [15].

Nevertheless, most of the endophytic microbes were able to stimulate plants growth in the seedling phase, but they might not able to show better effects to plants that has been tranplanted to the field. In addition, it is also not necessarily be able to better suppress the effects of stress on the environment, for 
http://wjst.wu.ac.th

example the development of the disease. As described by Rodriguez et al. [16], endophytic fungi were basically grouped into several classes. Endophytic fungi which were able to increase plant growth were grouped in Class 2, and which were able to improve plant resistance were grouped in Class-3. Therefore, the influence of the endophytic fungus on the development of bacterial wilt disease in vegetative and generative growth phase of chilli were conducted in semi-field level.
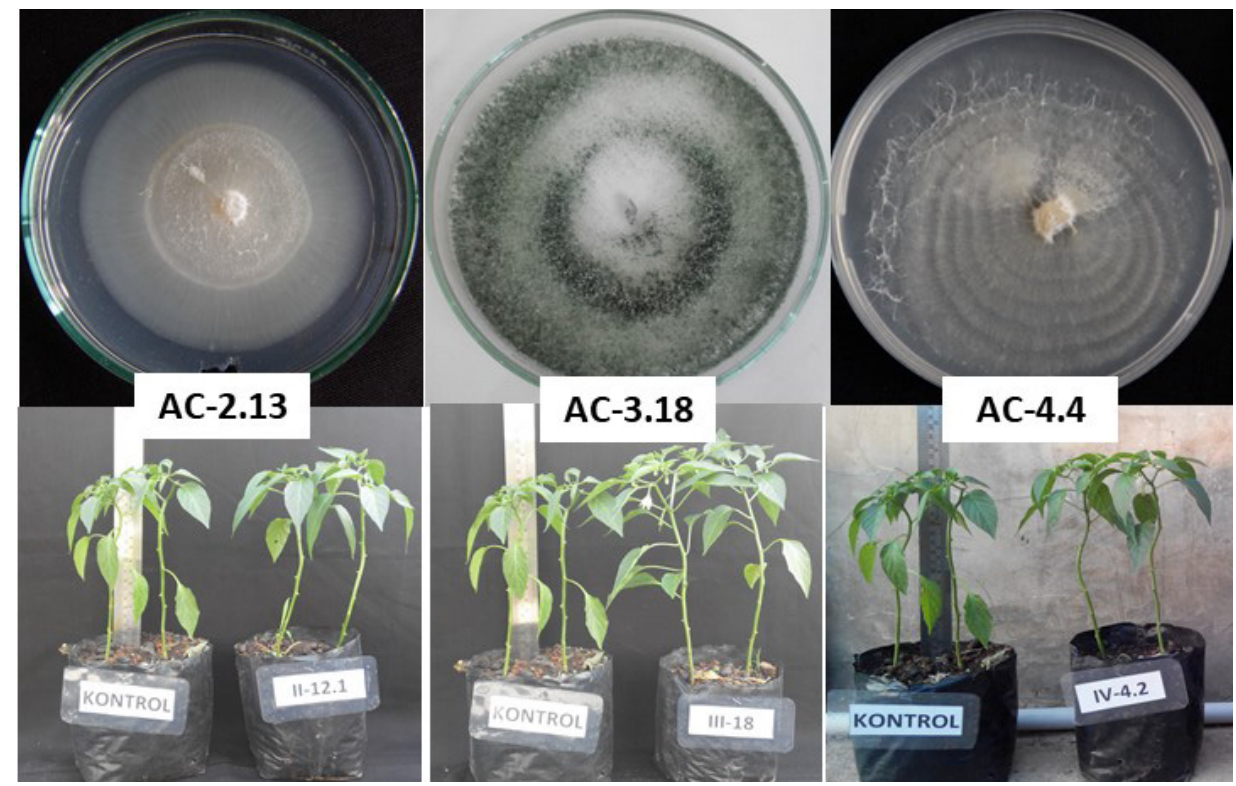

Figure 2 The effects of endophytic fungal isolates were applied singly to suppress the development of chilli wilt disease by $R$. solanacearum, seven days after inoculation (isolates AC-2.13 / II-12.1 and AC4.4 / IV-4.2 are Fusarium solani f.sp. phaseoli; isolate AC-3.18 / III-18 = Trichoderma asperellum; Kontrol $=$ chilli without applicated control agents).

\section{The effect of endophytic fungus to bacterial wilt disease intensity on chilli pepper}

Observations of bacterial wilt disease incidence and disease severity resulted from application of Fusarium sp. and Trichoderma sp. have shown that treatment of endophytic fungi either in single or combination application could reduce the disease intensity (Figure 3). There was a result displayed that the use of single isolate gave better result in suppressing the bacterial wilt disease than using combination treatments. Similar result was reported by Nawangsih [17] that single application biocontrol agents such as B. substilis AB89, P. fluorescens RH4003, and B. cereus L32 showed more suppression when compared to that of combination application. This fact could be clearly described by antagonistic relationship between those two or three bacteria if they were applied at the same time and same niche.The value of AUDPC has strengthened this phenomenon. AUDPC was one parameter which could describe the development gradient of plant disease progress. Higher value of AUDCP showed that disease in treatments develop rapidly with high rate than other treatments.

In addition, the effect of endophytic fungi application to the resistance of chilli pepper inoculated with $R$. solanacearum either singly or in combination also showed an effect on growth of chilli plants in field stage (semi field test). Other researchers reported that $T$. virens antifungal metabolites are known to suppress the development of Chinese kale leaf spots (Alternaria brassicola) at the field level up to $50 \%$, while the level of greenhouse up to $60 \%$, inhibits the germination of spores of more than $85 \%$ [18].

Research are rare regarding the use of endophytic fungi to control bacterial wilt disease by $R$. solanacearum, especially on chilli. Most reports of endophytic microbes used as control agents to $R$. 
http://wjst.wu.ac.th

solanaceraum are groups of bacteria. It has been reported that there was endophytic Bacillus which can suppress the incidence and severity of tomato wilt disease caused by $R$. solanacearum up to $100 \%$. In addition, the isolate was able to provide an increase in yields of more than $115 \%$ [19]. Other studies have reported that endophytic fungi have been found to reduce bacterial wilt disease in tomatoes caused by $R$. solanacearum up to $77.78 \%$. Besides endophytic of bacteria and endophytic Actinomycetes have also been known to suppress the incidence of the disease, up to 76.47 and $66.67 \%$, respectively [20].

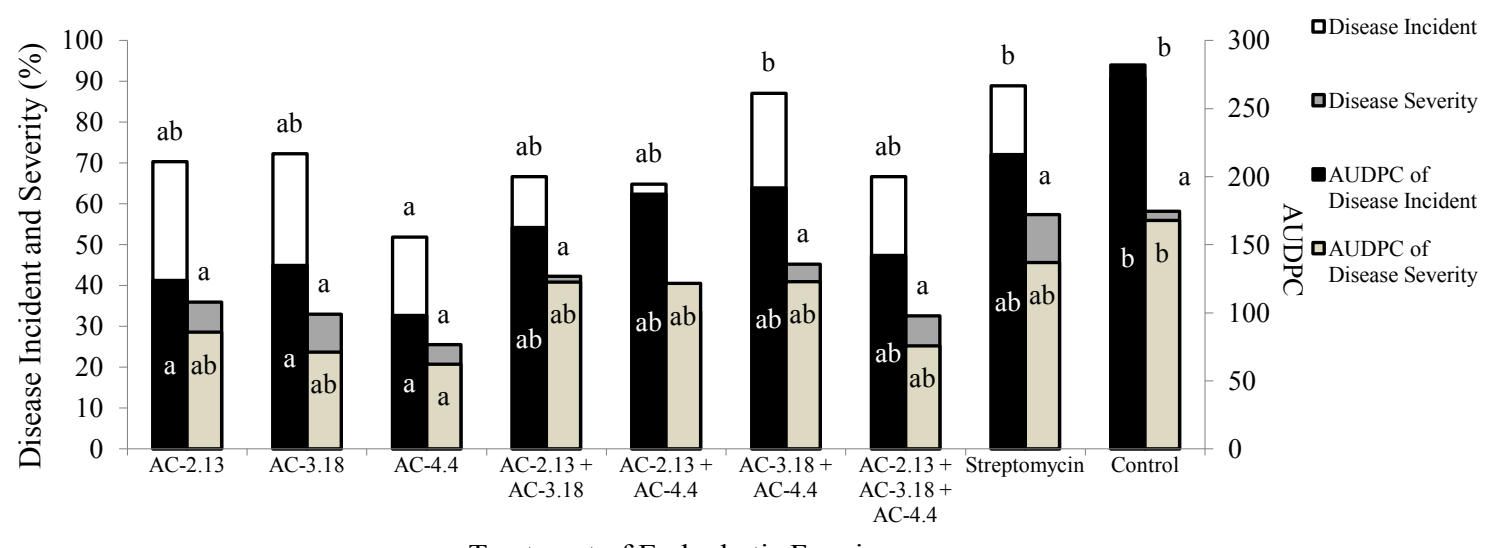

Treatment of Endophytic Fungi

Figure 3 Effects of endophytic fungus $F$. solani f.sp. phaseoli (isolates AC-2.13 and AC-4.4) and $T$. asperellum isolate AC-3.18 were applied single or in combination to the intensity of wilt disease (severity and incident of disease), and the area under disease progress curve (AUDPC) value on chilli until the age of 73 days after inoculation of pathogens (dai). The same letter in the same beam showed no significant difference in the Duncan's test $(\mathrm{p}>0.05)$.

\section{The effects of endophytic fungus on the growth and yield of chilli pepper}

In semi field test, generally the endophytic fungus that was used to suppress the development of bacterial wilt disease in chilli pepper, applied either singly or in combination. However, this capability was not always followed by the ability to promote plant growth. Based on the statistical analysis, the application of endophytic fungi either in single or in combination was also not giving significant effect to plant growth. Slightly different from the current state of the nursery, in the semi field condition (scale pot size), plants treated with single endophytic fungi applications were tended give better result in plant growth than result in combination treatment (Figure 4). However, based on the observation of plant growths, the application of endophytic fungi has given similar result compared to control such as plant height, number of branches, diameter of the canopy, and stem diameter. The treatment suggested that endophytic fungi has better or at least same with plant with no endophytic fungi. This result indicated that the presence of endophytic fungi did not give a negative effect on plant growth. This result must be clearly described because endophytic fungi may potentially could become pathogens. Generally, a treatment with the combination of T. asperellum isolates AC-3.8 and F. solani f.sp. phaseoli isolate AC4.4 had relatively showed best performance. The AUGPC values of agronomical characteristics (plant growth) had also shown similar result.

Statistically, endophytic fungi treatments did not provide significant impact on the plant growth of chilli pepper. However, single isolates treatment provided higher growth rate than a treatment combination. The application with $F$. solani f.sp. phaseoli isolate AC-4.4 has been known to trigger further growth in branches and stems than the others singly treated fungal endophyte. Meanwhile, the treatment with $F$. solani f.sp. phaseoli isolate AC-2:18, which was done in the seedlings were most likely 
http://wjst.wu.ac.th

trigger further growth even become more developed in semi-field trials. This phenomenon indicated that there might be a change/mobilisation of energy resulted from endophytic fungi activities. Treatment $F$. solani f.sp. phaseoli isolate AC-2:18 has shown higher growth promoting activities on chili pepper seedling. While on next growth vegetative phase, it was less triggered because the energy that was produced was more likely to be used to increase resistance to disease that triggered the growth in other phases (in generative growth). In contrary, the $F$. solani f.sp. phaseoli isolate AC-4.4 in the nursery lacked the growth but it grew more on the vegetative phase that had a better response to defense against bacterial wilt disease, if compared with isolates AC-2.18.

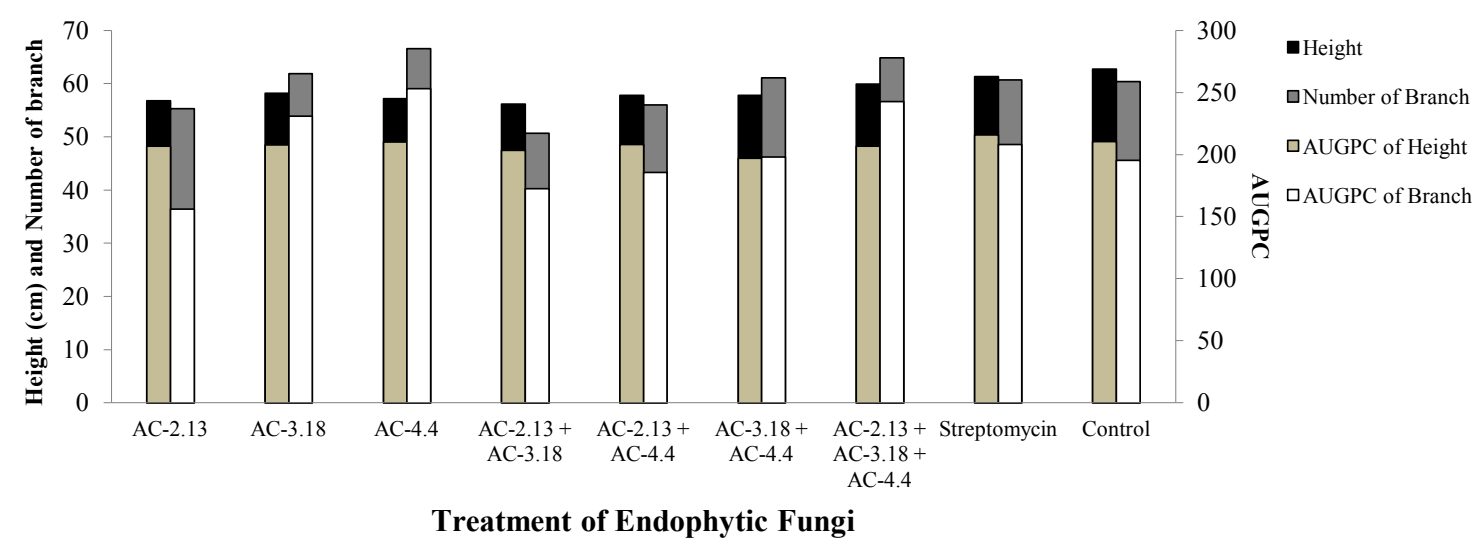

Figure 4 The effects of endophytic fungi isolate in plant inoculated with R. solanacearum were applied singly or in combination to height, number of branches, stem diameter, canopy diameter of chilli pepper plants and area under growth progress curve (AUGPC) up to the age of 98 days after transplanting (dat).

Bacterial wilt disease progress in generative stage of chili pepper has been observed. Endophytic fungi applied in combination treatment has obtained higher quantity crop yield (number and weight of fruits) than single treatment (Figure 5). This phenomenon was easily understood because endophytic fungi has a unique characteristic. Endophytic fungi that could suppress disease intensity would have a low contribution in increasing crop yield, and vice versa. The application of bacteriside showed the best result of crop yield. Rodriguez et al. [15], classified endophytic fungi based on some criteria, such as: host range, plant's colonized-part, ability to colonize, diversity in the soil, and its ecological function. From those criteria, the most correlated criterion was its ecological function. Endophytic fungi that has ecological function in controlling plant disease was classified in class 3 and class 4 . The difference of these two classes was its colonized-part and its diversity in the plant. Endophytic fungi from class 3 could only colonize plant shoot with high level of diversity. Meanwhile, endophytic fungi from class 4 could only colonize plant root with undefined diversity level.

Researchs about the use of microorganism as biocontrol agents usually started by evaluating its positive stimulation to the plant. Generally, antagonist agents that were used were selected from growthpromotor characteristic. Endophytic bacteria from the root of the tomato that promoted plant growth showed suppression in bacterial wilt disease progress [21]. Mentioned research method would share several advantages, such as: to obtain potential antagonist agents that does not only could promote plant growth but also could suppress plant disease. However, this advantage would be missed specifically phenomenon like case of the cluster above. Other researcher [3] reported that the use of T. viride in single or combination treatment with $P$. fluorescens, and B. subtilis could increase crop yield three times higher than control. 
The effects of endophytic fungus on the activity of compounds associated with chilli pepper defense system against bacterial wilt disease

Endophytic microbes that potentially controlled the pathogens that attack the vascular were generally observed through direct antibiosis mechanism. However, Irawati et al. [22] reported that $T$. asperellum isolate AC-3:18, isolates of $F$. solani f.sp. phaseoli AC-2.13 and AC-4.4 do not have any direct antibiosis activity against $R$. solanacearum. Several studies on the mechanisms of plant resistance to R.solanacearum were commonly associated with chemicals of active resistance i.e. hypersensitive reactions and antimicrobial compounds (phenol, phytoalexin). Observation about induce resistance mechanism was done by measuring the activity of several compounds related to plant defense systems, i.e. total phenol, total protein, peroxidase (PO), polyphenol oxidase (PPO), $\beta$-glucanase, and phenylalanine aminaliase (PAL) $[12,17,23,24]$. The results observation showed that generally, the application of endophytic fungus treatment changed the activity of various compounds significantly, except for the compound PO. However, the activity of total phenol, total protein, PO, PPO, and PAL was smaller in single fungal endophyte treatment than in combination, while the activity of $\beta$-glucanase was the other way around (Table 1).

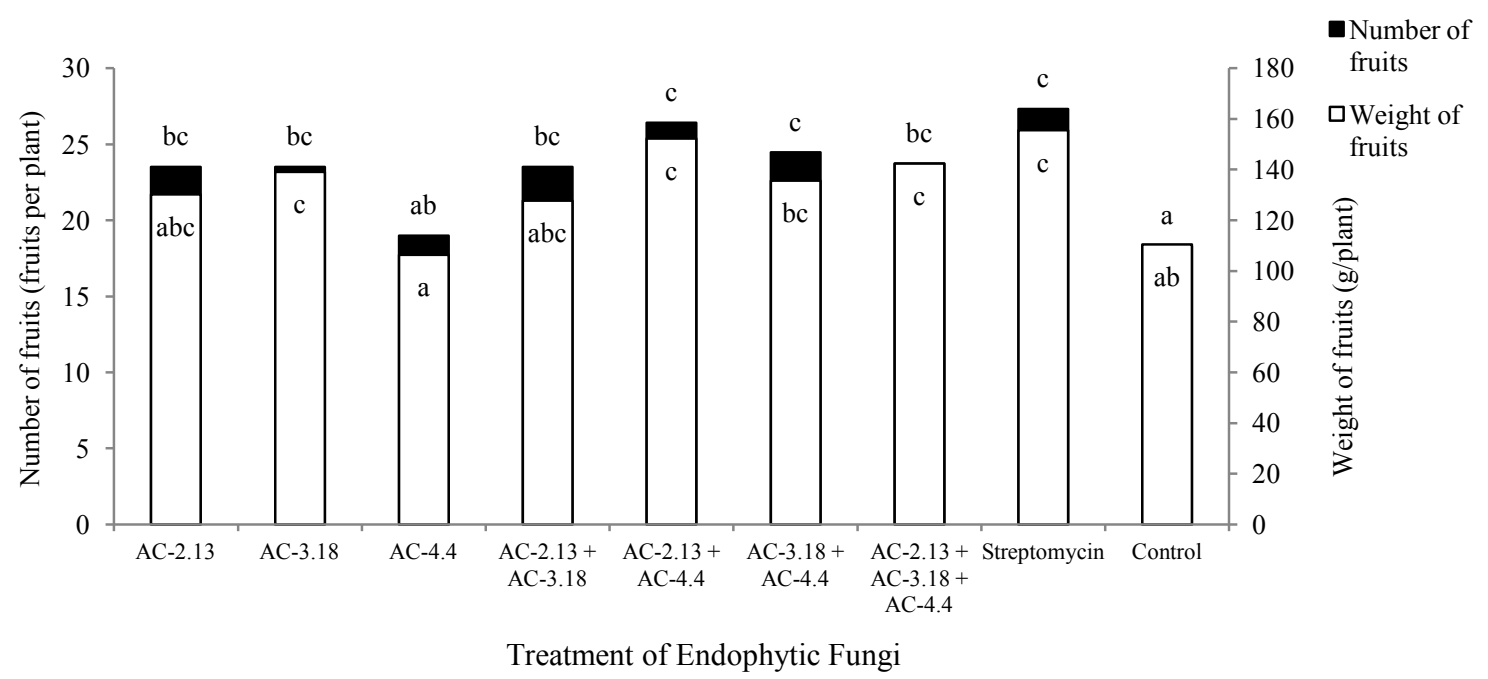

Figure 5 Effect of endophytic fungal isolates (F. solani f.sp. phaseoli isolates AC-2.13 and AC-4.4 and T. asperellum isolate AC-3.18) were applied singly or in combinations to average of weight and number of fruits per plant chilli pepper.

Generally, the treatment of single $F$. solani f.sp. phaseoli isolate AC-4.4 showed the best result in suppressing bacterial wilt disease. It also showed the change of PPO and PAL activity that was significantly higher when compared to other treatments. PPO and PAL are the precursor compounds that facilitate the formation of several plant defense systems, especially antimicrobial compound. However, almost all of the treatments with endophytic fungi applications showed the effects of reduction in total protein, except in treatment of $F$. solani f.sp. phaseoli isolate AC-2:13. The reduction of total protein was probably due to an enzyme or other protein compounds which was depressed or utilized by endophytic fungi to support its metabolic activity.

Generally, F. solani f.sp. phaseoli was known as the root rot pathogens in bean. However, Mostafavi et al. [22] reported that an artificial mutant of $F$. solani f.sp. phaseoli with gamma radiation was capable to change the nature of pathogenic to non-pathogenic that could suppress the disease caused by the pathogenic isolates. 
http://wjst.wu.ac.th

Tabel 1 Changes in the activity of total phenol, total protein, peroxidase (PO), polyphenoloksidase (PPO), $\beta$-glucanase, and phenylalanine aminaliase (PAL) in chilli application by the endophytic fungus, a week before and after inoculation of pathogenic bacteria wilt on chilli pepper.

\begin{tabular}{|c|c|c|c|c|c|c|}
\hline \multirow{2}{*}{ Treatment } & \multicolumn{6}{|c|}{ Compounds associated with chilli defense system } \\
\hline & $\mathbf{A}$ & B & $\mathbf{C}$ & D & $\mathbf{E}$ & $\mathbf{F}$ \\
\hline $\mathrm{AC}-2.13$ & $2.62 \mathrm{a}$ & $1.73 \mathrm{c}$ & -0.09 a & $-0.05 \mathrm{ab}$ & $1.05 \mathrm{bc}$ & $-1.22 \mathrm{ab}$ \\
\hline $\mathrm{AC}-3.18$ & $4.88 \mathrm{ab}$ & $-4.41 \mathrm{ab}$ & $0.25 \mathrm{a}$ & $0.62 \mathrm{ab}$ & $1.00 \mathrm{bc}$ & $0.36 \mathrm{ab}$ \\
\hline AC-4.4 & $6.81 \mathrm{~b}$ & -6.03 a & -0.06 a & $1.58 \mathrm{~b}$ & $0.79 \mathrm{bc}$ & $1.84 \mathrm{~b}$ \\
\hline $\mathrm{AC}-2.13+\mathrm{AC}-3.18$ & $6.37 \mathrm{~b}$ & $-4.04 \mathrm{ab}$ & 0.97 a & $1.02 \mathrm{ab}$ & $0.28 \mathrm{ab}$ & $-1.18 \mathrm{ab}$ \\
\hline $\mathrm{AC}-2.13+\mathrm{AC}-4.4$ & $4.53 \mathrm{ab}$ & $-1.91 \mathrm{bc}$ & $0.32 \mathrm{a}$ & $0.31 \mathrm{ab}$ & $0.09 \mathrm{ab}$ & $-1.85 \mathrm{ab}$ \\
\hline $\mathrm{AC}-3.18+\mathrm{AC}-4.4$ & $3.33 \mathrm{ab}$ & $-0.33 \mathrm{bc}$ & $0.52 \mathrm{a}$ & $-0.01 \mathrm{ab}$ & $-0.35 \mathrm{a}$ & $-2.28 \mathrm{ab}$ \\
\hline $\mathrm{AC}-2.13+\mathrm{AC}-3.18+\mathrm{AC}-4.4$ & $6.18 \mathrm{~b}$ & $-3.81 \mathrm{abc}$ & 0.26 a & -0.23 a & $0.55 \mathrm{abc}$ & -1.90 a \\
\hline Streptomycin & $4.38 \mathrm{ab}$ & $0.20 \mathrm{bc}$ & $1.23 \mathrm{a}$ & $-0.02 a b$ & $1.55 \mathrm{c}$ & $0.05 \mathrm{ab}$ \\
\hline Control & $6.27 \mathrm{~b}$ & $-2.32 a b c$ & $1.10 \mathrm{a}$ & $0.55 \mathrm{ab}$ & $1.59 \mathrm{c}$ & $1.18 \mathrm{ab}$ \\
\hline
\end{tabular}

Notes: (A) Total Phenols (mg chatecol/mg protein); (B) Total Protein ( $\mathrm{mg} / \mathrm{g}$ tissue $\left.\times 10^{-5}\right)$; (C) PO $\left(\Delta \mathrm{OD} /\right.$ minute $/ \mathrm{mg}$ protein $\left.\times 10^{-5}\right)$; (D) PPO $\left(\Delta \mathrm{OD} /\right.$ minute $/ \mathrm{mg}$ protein $\left.\times 10^{-3}\right)$; (E) $\beta$-Glucanase $(\mathrm{mg}$ sugar $\mathrm{DNS} / \mathrm{mg}$ protein $\left.\times 10^{-5}\right)$; dan $(\mathrm{F}) \mathrm{PAL}\left(\Delta \mathrm{OD} /\right.$ minute $/ \mathrm{mg}$ protein $\left.\times 10^{-4}\right)$.

\section{Conclusions}

In general, the application of $F$. solani f.sp. phaseoli and $T$. asperellum endophytic fungus singly or in combination can reduce the development of bacterial wilt in chilli pepper caused by $R$. solanacearum. However, some endophytic fungi that were potentially suggested as antagonist agents have not shown best performance in decreasing bacterial disease if combined with other antagonist agents. The ability to suppress the disease stimulated by endophyte fungi application was not always followed by its ability to increase crop yields. Generally, the activity of the compounds related to plant defense systems has increased, particularly PPO and PAL compounds. However, an increase in total protein does not always follow.

\section{Acknowledgements}

The author thanks the Agency for Research and Development of the Agriculture Ministry Republic of Indonesia on the funding given to the implementation of this study, through the State Budget FY 2015 Long-Term Training Program (Learning Officer).

\section{References}

[1] U Khairul. 2005, Study of Integrated Control to Bacterial Wilt Disease in Chilli Pepper, Ph. D. Dissertation, Bogor Agriculture University, Bogor, Indonesia.

[2] T Arwiyanto, M Goto, S Tsuyumu and T Takikawa. Biological control of bacterial wilt of tomato by an avirulent strain of Pseudomonas solanacearum isolated from Strelitzia reginae. Ann. Phytopathol. Soc. Jpn. 1994; 60, 421-30.

[3] Nurjanani. Control of bacterial wilt disease (Ralstonia solanacearum) use biological agents on tomato. Superman: Suara Perlindungan Tanaman 2011; 4, 1-6. 
http://wjst.wu.ac.th

[4] MM Tahat and K Sijam. Ralstonia solanacearum: The bacterial wilt causal agent. Asian J. Plant Sci. 2012; 9, 385-93.

[5] N Suharti, T Habazar, N Nasir, Dachryanus and Jamsari. Induction of ginger's resistance to wilt disease that caused by Ralstonia solanacearum Ras 4 with use indigenus of Fungi Mikoriza Arbuskular (FMA). J. Hama Penyakit Tumbuhan Tropika 2011; 11, 102-11.

[6] B Schulz and C Boyle. "What are endophytes?” In: B Schulz, C Boyle and TN Sieber (Eds.). Soil biology: Microbial root endophytes. $4^{\text {th }}$ ed. Springer, Verlag Berlin Heidelberg, 2006, p. 1-13.

[7] S Sundaramoorthy, T Raguchander, N Ragupathi and R Samiyappan. Combinatorial effect of endophytic and plant growth promoting rhizobacteria against wilt disease of Capsicum annum L. caused by Fusarium solani. Biol. Control. 2012; 60, 59-67.

[8] N Nantawanit, A Chanchaichaovivat, B Panijpan and P Ruenwongsa. Induction of defense response against Colletotrichum capsici in chili fruit by the yeast Pichia guilliermondii strain R13. Biol. Control. 2010; 52, 145-52.

[9] EP Ramdan, Widodo, ET Tondok, S Wiyono and SH Hidayat. Nonpathogenic fungal endophytes from chili pepper and their potential as growth promoting agent. J. Fitopatol. Indones. 2013; 9, 14439.

[10] KL Reynodls and DA Neher. Statistical Comparison of Epidemics. In: LJ Francl and DA Neher (Eds.). Excercises in Plant Disease Epidemiology. APS Pres, Minnesota, 1997, p. 35-7.

[11] R Anand, L Paul and C Chanway. Research on endophytic bacteria: Recent advances with forest trees. Soil Biol.: Mikrob. Root Endophytes 2006; 9, 106-89.

[12] KN Murthy, F Uzma, Chitrashree and C Srinivas. Induction of systemic resistance in tomato against Ralstonia solanacearum by Pseudomonas fluorescens. Am. J. Plant Sci. 2014; 5, 1799-811.

[13] AFC Irawati, Y Sastro, Sulastri, MT Suhartono, KH Mutaqin and Widodo. Endophytic fungi potentially increase resistance of chilli pepper against bacterial wilt disease. J. Hort. Indones. 2017; 27, 105-12.

[14] A Agusta. Biology and Chemical of Endophytic Fungi. $1^{\text {st }}$ ed. Penerbit ITB, Bandung, Indonesia, 2009.

[15] RJ Rodriguez, JF White, AE Arnold and RS Redman. Fungal endophytes: Diversity and functional roles. New Phytol. 2009; 182, 314-30.

[16] AA Nawangsih. 2006, Selection and Characterization of Biocontrol Bacteria to Bacterial Wilt Disease (Ralstonia solanacearum) in Tomato. Ph. D. Disertation. Bogor Agriculture University, Bogor, Indonesia.

[17] ZVT Handini and AA Nawangsih. The effectiveness of endophytic bacteria and plant growth promoting rhizobacteria as biocontrol agents of tomato bacterial wilt disease. J. Fitopatol. Indones. 2014; 10, 61-7.

[18] W Intana, T Suwanno and C Chamswarng. Use of antifungal metabolite from Trichoderma virens for controlling chinese kale leaf spots caused by Alternaria brassicicola. Walailak J. Sci. Tech. 2005; 2, 1-9.

[19] Y Yanti, Warnita, Reflin and CR Nasution. Characterizations of endophytic bacillus strains from tomato roots as growth promoter and biocontrol of Ralstonia solanacearum. Biodiversitas 2018; 19 , 906-11.

[20] D James and SK Mathew. Antagonistic activity of endophytic microorganisms against bacterial wilt disease of tomato. Int. J. Current Adv. Res. 2015; 4, 399-404.

[21] AA Nawangsih and FF Wardani. Interaction between endophytic bacteria and plant growthpromoting rhizobacteria to control bacterial wilt disease on tomato. J. Fitopatol. Indones. 2014; 10, $145-52$.

[22] AFC Irawati, Y Sastro, Sulastri, MT Suhartono, KH Mutaqin and Widodo. Endophytic fungi potentially increase resistance of chilli pepper against bacterial wilt disease. J. Fitopatol. Indones. 2016; 12, 133-41.

[23] HH Zhu and Q Yao. Localized and systemic increase of phenol in tomato roots induced by Glomus versiforme inhibits Ralstonia solanacearum. J. Phytopathol. 2004; 152, 537-42. 
http://wjst.wu.ac.th

[24] F Liu, F Wei, L Wang, H Liu, X Zhu and Y Liang. Riboflavin activates defense responses in tobacco and induces resistance against Phytophthora parasitica and Ralstonia solanacearum. Physiol. Mol. Plant Pathol. 2010; 74, 1064-8.

[25] HA Mostafavi, SM Mirmajlessi, N Safaie, V Minassyan, H Fathollahi, HR Dorri and SM Mansouripour. The use of a gamma-irradiated mutants of $F$. solani f.sp. phaseoli with reduced pathogenicity for the biological control of Fusarium root rot of bean (Phaseolus vulgaris) in field conditions. J. Agr. Sci. Tech. 2012; 14, 1415-23. 